Viso - Cadernos de estética aplicada Revista eletrônica de estética

ISSN 1981-4062

№ 3, set-dez/2007

http://www.revistaviso.com.br/

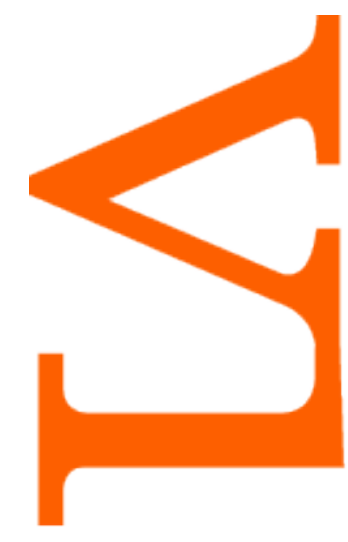

\title{
O aprendiz do belo: a arte-ética em Plotino Marcus Reis
}




\section{RESUMO}

\section{O aprendiz do belo: a arte-ética em Plotino}

O artigo apresenta as características básicas da estética em Plotino, procurando esclarecer as imbricações necessárias entre estética e a proposta ética de conversão rumo ao inteligível. A arte se mostra como um processo de descoberta daquilo que é mais propriamente nosso, de nosso nível mais verdadeiro, o noûs. Na auto-descoberta apaixonada do noûs, o aprendiz do Belo se torna sua maior obra de arte, a escultura de si mesmo, que faz brilhar em sua própria vida o resplendor da virtude, mimese do inteligível. Também o artista, na nossa acepção do termo, ao criar sua obra exterior, faz brilhar sensivelmente os seus amores inteligíveis, unificando-se progressivamente com as esferas superiores. Suas obras são frutos do processo de conversão ao mundo das verdadeiras belezas, o noûs. Tais obras, cópias diretas do mundo inteligível (e não cópias de copias), são vestígios Daquele Belo, indicações que nos apontam para a transcendência, são obras-anaminese, que nos fazem escalar o caminho da ascese: arte-ética, a vida como um ato de artista.

Palavras-chave: filosofia antiga - platonismo - ontologia - Plotino

\section{ABSTRACT}

He who learns beauty: art-ethics in Plotinus

This paper presents the basic features of Plotinus' aesthetics and seeks to establish the necessary relations between aesthetics and ethical idea of conversion to the intelligible. Art is a process by which we discover that which is most properly ours, the noûs. Through the loving self-descovery of noûs, he who learns Beaulty becomes his greatest work of art, a sculpture of himself, which shines in his own life the splendor of virtue, an immitation of the intelligible. An artist in the proper sense of the word also makes his intelligible love shine in the sensibility, thus gradually joining the superior spheres. His works result from one's gradual conversion to the world of real beauties, the noûs. As direct copies of the intelligible world (and not copies of copies), such works bear traces of that Beauty, indications of transcendence, they are anaminese works that put in the ascetic path: art-ethics, life as the act of an artist.

Keywords: ancient philosophy - Platonism - ontology - Plotinus 


\section{REIS, M. "O aprendiz do belo: a arte-ética em Plotino". In: Viso: Cadernos de estética aplicada, v. I, n. 3 (set- dez/2007), pp. 18-32.}

\section{$10.22409 / 1981-4062 / v 3 i / 44$}

Aprovado: 29.11.2007. Publicado: 27.12.2007.

(c) 2007 Marcus Reis. Esse documento é distribuído nos termos da licença Creative Commons Atribuição-NãoComercial 4.0 Internacional (CC-BY-NC), que permite, exceto para fins comerciais, copiar e redistribuir o material em qualquer formato ou meio, bem como remixá-lo, transformá-lo ou criar a partir dele, desde que seja dado o devido crédito e indicada a licença sob a qual ele foi originalmente publicado.

Licença: http://creativecommons.org/licenses/by-nc/4.0/deed.pt_BR

Accepted: 29.11.2007. Publicado: 27.12.2007.

(c) 2007 Marcus Reis. This document is distributed under the terms of a Creative Commons Attribution-NonCommercial 4.0 International license (CC-BY-NC) which allows, except for commercial purposes, to copy and redistribute the material in any medium or format and to remix, transform, and build upon the material, provided the original work is properly cited and states its license.

License: http://creativecommons.org/licenses/by-nc/4.0/ 
A filosofia de Plotino busca ir além da filosofia. Constrói-se como uma prática discursiva que se desenvolve em meio à impossibilidade de dizer aquilo que é o mais importante, como um discurso que ao falar procura conclamar ao silêncio. Nesta tarefa, em que utiliza armas que deve abandonar - o próprio discurso -, a filosofia de Plotino se torna uma experiência apaixonada daquilo que busca. A paixão, Éros, pelo mundo Inteligível e, além deste, por aquilo que a tudo transcende, o Uno-Bem, é a tônica da obra de Plotino, e na medida em que a estética se reporta ao Belo, que é objeto do Éros, deve-se pensar toda obra de Plotino como uma estética.

No entanto, é bastante delicado afirmar, sem mais, que há uma estética em Plotino, mesmo sendo o Licoplitano $^{1}$ particularmente conhecido pela sua contribuição aos questionamentos sobre a estética. Ao falarmos de estética em Plotino, não podemos deixar de lado o fato de que não há, na Antigüidade, uma investigação que seja exclusivamente estética: ao se tratar sobre o belo e a arte, nunca se deixa de lidar com temas éticos, epistemológicos e ontológicos. Assim, veremos neste artigo o modo como Plotino lida com os temas da estética sempre nos remetendo às compreensões mais profundas de sua filosofia.

A título de introdução, começamos este artigo apresentando algumas noções gerais das Enéadas e da metafísica de Plotino, que nem sempre são tão óbvias para qualquer leitor. A obra de Plotino foi editada por seu aluno Porfírio, que a organizou em seis volumes com nove tratados cada um, e, por isso, cada volume foi denominado Enéada (que contém nove), formando ao todo 54 tratados. De acordo com Porfírio, a organização das Enéadas é temática: a primeira lida com a ética, a segunda e a terceira com a física, e as restantes seguem a ordem hierárquica da metafísica de Plotino: a quarta lida com a Alma, a quinta com o Intelecto, a sexta com o Uno. Para alcançar tal perfeição sistemática, o aluno-editor teve que dividir e reagrupar certos tratados na ordem que ele acreditava ser a melhor, mas teve também a generosidade de nos deixar a suposta ordem cronológica em que Plotino teria escrito esses tratados. Assim, ao citar um tratado, normalmente cita-se tanto o número, entre colchetes, que remete à sua posição cronológica no âmbito da obra de Plotino, quanto os números referentes à localização em que Porfírio o colocou. ${ }^{2}$

\section{A Descida a partir do Uno}

Nas Enéadas, Plotino postula três hipóstases ${ }^{3}$ que comporiam a realidade total, o Uno, hén, o Intelecto, ou Espírito, noûs e a Alma, psyché, e as organiza hierarquicamente, tendo o Uno como hipóstase superior a partir da qual se processaria o Intelecto e deste, a Alma. A imagem cunhada por Narbonne de um chafariz com três quedas, cada uma jorrando água em uma grande circunferência que transborda para a próxima é bem clara para entendermos o intrincado sistema plotiniano. 
Partindo da passagem da República em que o Bem é postulado como sumamente transcendente, isto é, além do ser, epékeina tês ousías, Plotino formula uma radical simplicidade para o princípio de toda a realidade, o Uno-Bem. Apesar destes qualificativos (Uno e Bem), o Uno está além de toda linguagem, e esse nome, Uno, é apenas uma forma negativa de afirmar-lhe a falta de multiplicidade. Daqui provém a chamada Teologia Negativa, que será tão importante em Dionísio Areopagita. O Uno permanece eternamente em seu próprio ato, nos diz Plotino utilizando um linguajar aristotélico. Em verdade, o Uno não tem necessidade de nada, permanece [menein] em seu ato auto-criativo, mas, no entanto, há algo que irradia dele, que se processa a partir de seu ato.

Uma das principais questões para a filosofia antiga, de acordo com o próprio Plotino ${ }^{4}$, era como do uno poderia ser gerado o múltiplo. As hipóstases se diferenciam exatamente quanto ao maior número de seres, já que em cada hipóstase há maior multiplicidade e complexidade. Assim, o Intelecto é mais múltiplo que o Uno, e a Alma mais múltipla que o Intelecto. Para sermos exatos, Plotino propõe três etapas de constituição de uma hipóstase subseqüente: (1) cada hipóstase permanece em si mesma, mas com isso também é (2) gerada a processão que produz uma massa informe, que precisa (3) se voltar para a hipóstase anterior e contemplá-la, para assim se formar a si mesma. Esse terceiro passo, de acordo com Gatti ${ }^{5}$, é talvez o aspecto mais genial e original da filosofia de Plotino. Vamos descrever esse processo de modo sucinto.

Em um primeiro momento ${ }^{6}$, o Uno permanece em seu próprio ato, sem se importar ou se voltar para nada além de si mesmo. No entanto, há uma processão que sai a partir dele, formando uma massa ainda não determinada. Essa massa, às vezes qualificada como "ser indefinido", volta-se, epistrophé ${ }^{7}$, para o Uno e faz deste seu objeto principal, contemplando-o: nessa contemplação e conversão desse ser indefinido em direção ao Uno forma-se o Espírito, ou Intelecto, o noûs. Como nos diz Reale, "[...] deve-se salientar que o poder e a atividade do Uno não geram sem mais o noûs e sim algo de 'indeterminado', ou 'informe', e este se determina e se torna 'mundo das formas' voltando-se para o Uno, olhando e contemplando o Uno [...]". ${ }^{8} \mathrm{O}$ ato próprio do noûs é a contemplação permanente do Uno, só que há um "primeiro movimento do noûs", que precede seu retorno ao Uno, e é chamado por Plotino de "matéria inteligível" ou "alteridade" ou até mesmo "Ser". O Intelecto se torna definido em sua contemplação do Uno e é, então, qualificado como o Uno-Muitos ${ }^{9}$, o Cosmos Inteligível, identificado com o mundo das idéias em Platão. ${ }^{10} \mathrm{O}$ Intelecto de Plotino é a união de Ser e Pensamento, feita já por Parmênides ${ }^{11}$, já que é a unidade do inteligível com a inteligência, do sujeito e do objeto do pensamento.

As qualificações mais recorrentes da hipóstase do noûs são Ser, Vida e Pensamento, e a partir de sua atividade principal provém novamente uma outra hipóstase: a da Psyché. Além de se voltar para o Uno, o Intelecto também se volta sobre si mesmo, pensando a si mesmo - ele é puro pensamento que interconecta todas as idéias - e nessa atividade 
gera para além de si outra forma ainda indefinida. Da mesma maneira, essa forma indefinida deve se voltar e contemplar o Intelecto ${ }^{12}$ : "[...] A Alma é o pensamento do Intelecto e é, num certo sentido, a sua atividade, assim como o Intelecto é pensamento e atividade que se refere ao Uno". ${ }^{13}$ Assim, dizemos que a Alma pensa, pois esse é o seu ato -voltar-se para contemplar o Intelecto - mas, em verdade, é apenas no noûs que reside o pensamento puro.

Novamente, a Alma em seu ato puro - a contemplação do noûs - gera para além de si uma realidade que é tão distante do primeiro princípio que já não tem mais força de constituir um ente auto-sustentável: a matéria é um não ser. ${ }^{14} \mathrm{Em}$ verdade, o mundo sensível seria algo que surge da própria Alma como um reflexo daquilo que é mais próprio dela, isto é, de seu ato mais elevado que é a contemplação do noûs. Neste sentido, seguindo Platão, o mundo sensível seria uma atividade da alma do mundo que copia o mundo inteligível. ${ }^{15}$

\section{A subida rumo ao Uno}

Uno, Intelecto e Alma, Processões e Conversões, Imagem e Original e Original que copia outro Original, o sibilino sistema de Plotino: um chafariz com três quedas, cada uma jorrando água em uma grande circunferência que transborda para a próxima. Contemplamos argumentos alabirintados, e a beleza será nosso fio de Ariadne rumo à Saída. Sigamos em frente para pensar de que modo a ética se manifesta no seu sistema.

Novamente, seguindo bem de perto Platão, Plotino afirma que o objetivo máximo da alma humana é retornar para Lá [ekei], aquele lugar mesmo de onde ela se originou, e o convite para este retorno é feito pela beleza. A beleza se encontra no centro das especulações éticas de Plotino, pois é ela que naturalmente solicita o homem a galgar os degraus da ascese. Na medida em que há uma supremacia da beleza na filosofia de Plotino - beleza esta que se manifesta tanto na arte [tekhné] quanto no rosto do amado [eromenos], quanto nas especulações racionais [logos] - o Artista [mousikós], o Amante [erastés] e o Filósofo têm certo privilégio nesta jornada de ascensão rumo ao Princípio.

Na nossa tentativa de descrever a noção de beleza em Plotino, perceberemos sua caracterização dupla e parcialmente contraditória: a beleza se encontra e ao mesmo tempo não se encontra em cada um dos níveis desta subida. Na medida em que a sua metafísica hierárquica é estruturada em níveis que copiam os níveis anteriores, a beleza que se encontra no noûs estará também presente, de alguma maneira, em cada uma das esferas inferiores. Portanto, apesar de a beleza se encontrar mais intensamente em uma esfera superior, mesmo nesta maior intensidade ainda será necessário ultrapassála. O original, que antes era o paradigma, se torna nova cópia, convidando para novo movimento de superação. Mesmo com toda paixão da descoberta de um novo grau de intensidade da beleza, a saudade do além retorna, insidiosamente, a nos acordar para 
continuar a jornada.

Fica claro que a Beleza é tão cara a Plotino porque também o era para o Divino Platão. No mestre, assim como no nosso neoplatônico, o esforço pessoal de transformação é o meio de compreender o Belo: estética e ética. Tanto no célebre Banquete, no discurso de Diotima $^{16}$, quanto no Fedro, especialmente no segundo discurso sobre Éros ${ }^{17}$. Platão apresenta claramente a busca pela Beleza vinculada a uma ascese.$^{18}$ De acordo com a mais íntima conexão entre ética e estética, a possibilidade de compreensão da Beleza está no exercício [áskesis] de transformação pessoal rumo aos níveis superiores da realidade.

Citando o próprio $\mathrm{Fedro}^{19}$, Plotino, em um de seus tratados ${ }^{20}$, vai afirmar que há três naturezas humanas aptas à viagem rumo a estes níveis superiores: a do músico ${ }^{21}$, a do amante e a do filósofo. O músico e o amante começam seu processo de aprendizagem pelo próprio mundo sensível, já o filósofo consegue naturalmente perceber a beleza dos outros níveis. Os primeiros devem, então, aprender sobre a origem da beleza. Mas antes de passarmos para a superação do sensível, vale citar a definição de beleza sensível: "afirmamos que é pela participação nas idéias que estas coisas são belas". ${ }^{22}$ Ser belo é participar nas formas perfeitas que residem no noûs e são contempladas pela alma, e certamente não se esgota no sensível.

Assim, tal amor ao sensível deve ser refinado e aprofundado. Como na escalada erótica proposta por Diotima no Banquete $^{23}$, o amante e o músico precisarão aprender que a beleza contemplada no mundo sensível - para um, no rosto do amado, para outro, no encadeamento das notas e da poesia - provém de uma outra ordem da realidade, cuja descoberta é necessária. O primeiro passo da subida consiste em perceber certos entes belos cuja existência não pode ser restrita ao mundo corpóreo: as ciências, as virtudes, as atitudes belas não podem ser compreendidas como realidades corpóreas. $\mathrm{O}$ amante $\mathrm{e}$ o músico devem ser educados a verem beleza também nos objetos que não os sensíveis, e devem perceber ali sua maior intensidade. Dá-se, então, um primeiro passo na subida ética proposta por Plotino: o encantamento com a beleza do mundo sensível e a correspondente saída para outro nível.

Ao ultrapassar o nível sensível, percebe-se a vastidão da psyché. As virtudes, os discursos, o movimento matemático das esferas celestes, todas estas realidades passam a encantar aquele aprendiz que começa a superar suas antigas paixões, descobrindo, mesmo que dolorosamente, novas intensidades daquilo mesmo que amava. No entanto, ao alcançar o nível da psyché, o aprendiz do Belo ainda se encontra em uma multiplicidade de elementos que proporcionam beleza. Dentro do que Plotino propõe para a psyché, podemos distinguir pelo menos quatro níveis: a alma individual, a alma das esferas celestes, a alma do mundo e a alma-hipóstase, esta última sempre voltada para o noûs. Cada um destes níveis da psyché de Plotino valeria um estudo à parte, mas podemos indicar alguns traços gerais. 
A psyché não se restringe apenas ao âmbito individual, que organiza e doa beleza ao homem, mas também abarca a alma do mundo, que organiza e doa beleza para o próprio cosmos. Há kósmos, isto é, ordem e beleza na própria natureza, e seus movimentos de nascimento e morte são presididos por uma força que a tudo comanda. As estações se seguem ordenadamente, os animais procriam e morrem respeitando uma ordem, as chuvas e rios parecem saber que são governados e supervisionados por uma alma do mundo que, como uma grande mãe, dispõe e cuida o melhor possível de tudo o que ocorre. Ao levantar a cabeça para os céus, nosso aprendiz do Belo percebe ainda que o próprio movimento cíclico cósmico é ordenado pelo que há nele de noético, o que há nele de inteligível: o movimento matemático dos astros. ${ }^{24}$ Surge, para o aprendiz extasiado de beleza, o Inteligível que a própria alma contempla em seu organizar diário das coisas do mundo. A maior intensidade psíquica de belo se torna ainda pequena, e a nostalgia do mais expande-se no coração daquele que ama o Belo. Continua-se, rumo ao noûs.

Surge, refulgente, o novo vasto mar de beleza ${ }^{25}$, aquele mesmo que é paradigma das atividades anímicas. Percebe-se um novo nível de beleza, o do noûs, pois a subida erótica não termina no nível da psykhé. $\mathrm{O}$ aprendiz de beleza deve perceber que $\mathrm{o}$ ato específico da alma, aquele que proporciona ser e beleza, é a contemplação de uma esfera ainda superior, aquela do noûs, do Intelecto. Ao se identificar com o Inteligível, a alma encontra aquilo que ela realmente ama, a Beleza em si mesma. Nesta hipóstase, tudo brilha, tudo cintila com o resplendor da Beleza que perpassa todas estas realidades superiores: as Formas. Na medida em que estamos no âmbito dos entes que realmente são, cada uma das realidades conterá o máximo de beleza e perfeição.

O estatuto deste Mundo Inteligível não é pouco complexo, e a sua investigação e descrição completa não cabe neste artigo. Mas uma imagem muito elucidativa para compreendê-lo é aquela apresentada no capítulo 9 do tratado 31, Sobre a beleza inteligível. Plotino sugere que imaginemos o cosmos como uma grande esfera, e que, então, retiremos tudo que há de corpóreo, áphele tês hýles, retendo apenas a forma do cosmos, como uma imensa esfera transparente [epí sphaíras diaphanoûs]. ${ }^{26}$ Esta imagem representa muito bem a interconexão entre todos os entes presentes no noûs: ao contemplar qualquer parte, estaremos contemplando o todo. Todas as Formas contêm, de alguma maneira, a totalidade do mundo inteligível e, assim, tudo ali é pura Beleza. Trata-se de um íntimo contato de tudo que ali se apresenta, de uma intrínseca conexão mútua. Tanto o artista quanto o amante encontram aqui o nível máximo de sua inspiração neste complexo de Formas, que é a hipóstase do noûs.

No entanto, a jornada ainda não acabou. Novamente, o original se torna cópia, e nos preparamos para nova subida. Plotino afirma claramente que mesmo sendo esta a esfera da Beleza, não se trata, no entanto, do último nível da realidade. Há algo ainda hyperkalos $^{27}$, além do Belo. A delicadeza e sutileza de Plotino ao tentar qualificar tal realidade sumamente transcendente - o Uno - como sendo ainda objeto do desejo 
humano, e ao mesmo tempo, encontrando-se além de todo ente, é bastante interessante. Como já foi dito aqui, o Uno é epékeina tês ousías, além de todo ser, e, portanto, nenhuma qualificação Ihe pode ser atribuída. A Beleza é o superlativo do ser [ousía], é aquilo que expressa a maior realidade do ser, e, no entanto, o Uno, o Bem se encontra para além de todo ser. Entretanto, por ser o sumamente amável, erasmiôtaton ${ }^{28}$, ele é também, de alguma maneira, belo: kállos hýper kállos, beleza além da beleza.

A alma identificada ao noûs percebe que não terminou sua jornada, pois percebe que há ainda algo mais amável do que o noûs, percebe que a própria dialética noética deve ser ainda ultrapassada. O noûs se apresenta também como amante, o noûs erôn[29], e o seu anseio é pelo sumamente transcendente, o Uno-Bem.

Para se compreender de modo mais apropriado toda a dimensão existencial desta escalada, deve-se descrever melhor o movimento ascensional necessário para a sua compreensão. A chave interpretativa da beleza inteligível e daquele Primeiro, que a transcende, é o trabalho pessoal proposto pelas Enéadas, e a partir deste trabalho perceberemos o lugar e a função da arte para Plotino.

\section{"Esculpir a própria estátua"}

Em um dos tratados mais famosos das Enéadas, o Sobre o Belo, I, 6 [1], Plotino é bastante claro ao afirmar a necessidade de um trabalho sobre si mesmo com vistas à compreensão da Beleza. Ora, na medida em que apenas aquele que a contempla pode realmente compreender a Beleza, e somente em um trabalho ético de aperfeiçoamento de si mesmo é possível contemplá-la (pois, em verdade, a contemplação ocorre através de uma identificação), epistemologia, ética e estética são inseparáveis em Plotino. Podemos perceber traços da necessidade prévia de uma identificação pessoal com a beleza inteligível em algumas passagens do tratado 1.

Quanto às belezas superiores - que já não cabe à percepção ver - a alma, sem órgãos, as vê e proclama, pois, para aqueles que contemplam, é necessário elevar-se, abandonando a percepção, que permanece embaixo. Assim como não é possível descrever aos que não vêem, caso forem cegos de nascença, as belezas da sensibilidade ou aos que não as reconhecem como belas, do mesmo modo não [é possivel descrever] a beleza das ocupações a não ser para os que as aceitam plenamente $[\ldots]^{30}$

Deve-se subir [anabatéon] de novo para o Bem, para aquilo que toda a alma deseja. Se alguém viu isto, sabe o que eu digo, em que sentido ele é belo [...] mas somente o obterão aqueles que subirem até 0 alto e se converterem, e ao se despir das vestimentas que receberam ao vir para baixo $[\ldots]^{31}$

A partir destas passagens, e ao longo deste tratado, percebemos como o foco do texto de Plotino é o trabalho ético necessário para a correta compreensão da Beleza. Vemos, 
então, que tal trabalho de ascese é o justo sentido da imbricação entre estética e ética na obra de nosso autor, pois a compreensão da Beleza passa necessariamente por um processo de transformação pessoal em que o aprendiz precisa reconhecer em si a Beleza. Todo o linguajar dos mistérios, presente também no diálogo Fedon, nos seduz à beleza e à força da kátharsis, o processo de purificação pessoal que expurga em nós o desejo pelo mundo corpóreo, alimentando o anseio pelo Além, pela identificação amorosa com o mundo noético. $O$ texto de Plotino, que espelha o diálogo vivo que ocorria em suas aulas ${ }^{32}$, é uma constante sedução noética, insuflando com seu linguajar simples e apaixonado o anseio pela identificação de nossa natureza com Aquela natureza da Beleza Inteligível. Na medida em que se trata de um impulso erótico, o conhecimento radical se concretiza no momento em que a alma se torna toda a extensão da beleza inteligível, isto é, no momento da conversão da psykhé em noûs. O processo de conversão de uma hipóstase inferior em uma superior é sempre de comunhão e unificação, tornando, neste caso, a alma idêntica àquilo que ela contempla: o noûs: pensamento e pensado são um. Na verdade, uma união amorosa de retorno entre um rebento-psykhé e o mar-noûs que the deu vida.

Tal prática noética de ascese pressupõe o trabalho, o exercício, que nos reporta necessariamente a Diógenes, o Cão, o pensador do mais árduo exercício de toda Antigüidade. Renúncia de tudo que for outro, afirmação e prática daquilo que for mais próprio, daquelas atividades mais autênticas, o exercício do que for mais meu: a filosofia de Plotino é, em certo sentido, a livre e nobre autarquia da postura Cínico-Socrática. Todo o mundo material, todo o exterior, simplesmente não pode dizer respeito àquele que busca a máxima liberdade. Ser como um cínico grego significa esforçar-se sobre si mesmo. Lembramos, então do auto-lapidamento de Plotino e chegamos, enfim, no famoso "esculpir a própria estátua".

A tarefa rumo ao Belo é sempre sobre aquele mesmo que o procura, e o aprendiz do Belo torna-se o próprio objeto a ser vasculhado, escrutinado. Tal é a obra do homem virtuoso que aceita a necessidade de uma experiência pessoal com o belo para a sua correta compreensão, e por isso busca o mergulho na beleza inteligível do noûs. Encontramos nas Enéadas imperativos de abandono, de limpeza, de se retirar o excesso, imperativos que descrevem o trabalho de um possível escultor que aprimora em si mesmo a sua estátua. Eis uma das mais belas passagens de Plotino:

Volte-se sobre ti mesmo, e olha. Se ainda não vês tu mesmo belo, como um criador de
esculturas que busca torná-las belas - ele retira uma parte, recorta a outra, outra faz
suave, outra ainda faz pura - desta forma também tu, retire o excesso, alinha aquilo que
for torto, trabalha sobre o que for obscuro, purifica-os, para que sejam brilhantes. E não
cesse de moldar sua própria escultura, até que o esplendor da virtude deiforme brilhe,
até que tu vejas a temperança fixada no trono sagrado. Se, tendo te tornado isto, tu
também vês isto, associe-se consigo mesmo de modo puro [...].

A experiência mística de identificação com um outro nível de realidade, o nível noético da Beleza, se torna uma experiência estética de realização do desejo mais profundo da 
alma. Experiência estética, conhecimento radical, felicidade e verdade estão aqui intimamente entrelaçados, pois se trata de uma realização superior da alma - a identificação com o noûs - que confere um novo sentido a todas as esferas humanas.

Com a imagem da escultura encontramos, indelével, a imagem de uma arte-ética, ou de uma ética-arte. Arte como vida, viver de modo artístico. ${ }^{33}$ Plotino nos apresenta uma compreensão estética da ascese ética, um exercício artístico de vida, uma prática artística, com o exemplo da arte plástica de moldar formas já indicando a realização do inteligível no sensível. A arte que nos é necessária é esculpir nossa própria pessoa, deixando-lhe o essencial, aquilo que lhe é mais próprio, a contemplação do inteligível. A grande obra artística de todos aqueles que buscam a realização do belo é a própria vida virtuosa, vida identificada com o mais sublime noûs.

No entanto, como já falamos desde o princípio, há um nível além do noûs, o Uno-Bem. Aproximamo-nos, agora, do mais hiperbólico da transcendência de Plotino: o epékeina tês ousías, o além do ser, além do além, a negatividade sumamente positiva da teologia negativa, que não se deixa apreender nem pela pujança e magnanimidade do noûs. Ao transcender um nível que já nos parecia transcendente, o noûs, adentramos em um âmbito de pura sobreeminência, do Uno Supremo, o Primeiro, a que nem a dialética alcança: abandona-se tudo, chega-se ao Puro Abandono. Em tal radicalidade de Além, nem se pode mais falar de Arte, nem de Belo, nem de Ser: logra-se, agora, em uma inesperada unificação, o ininteligível, o inefável, o Grande Outro, Hén-Agathós.

No entanto, Plotino sempre nos pega de surpresa, e nos apresenta um éros do próprio uno. Se o éros, na concepção grega que foi solidificada pela dialética com Diotima, é sempre em busca do Belo, e por isto um atestado de deficiência frente ao objeto amado, seria estranho descobrirmos o próprio Uno, pura perfeição, também como amante. 0 refinamento do pensamento de Plotino é sublime: trata-se de um auto-amante: "E ele é, também, amado, e amor e amor de si mesmo, e, sendo belo, não pode retirar sua beleza a não ser de si mesmo [...]". ${ }^{34}$ A complexidade de tal expressão em Plotino, erôs autoû, não é pequena, apesar dos poucos estudos mais aprofundados sobre esta passagem ${ }^{35}$, e aqui não é o lugar de tratarmos dela. Vale apenas a indicação. A rigor, o discurso sobre o Uno-Bem em Plotino é tão sutil que talvez devêssemos, ao falar de arte e estética, nos restringir ao amor da psyché pelo noûs, no qual encontramos explicitamente aquilo que se chama de belo.

\section{A arte em Plotino}

Já entrevimos a arte-ética da kátharsis da ascese plotiniana, mas falou-se pouco daquilo que entendemos hoje como arte. $\mathrm{O}$ tratado em que se encontra de modo mais lapidar a estrutura da arte em Plotino é o Sobre a Beleza Inteligível, V, 8 [31].$^{36}$ Ali, Plotino nos mostra que a beleza esculpida em uma pedra, por exemplo, se encontra de modo mais radical e intenso no artista que a esculpiu; mais intensamente ainda, esta beleza se 
encontra na própria arte, que parece estar identificada ao noûs. Nesta passagem encontramos lapidarmente formulada a repulsa à crítica de Platão sobre a arte, em que o ateniense afirma que a téchne de Homero seria a cópia do que já é cópia:

Mas se alguém despreza as artes [téchnas] porque estas produzem imitando [mimoúmenal] a natureza [phýsin], primeiro precisa ser dito que também as coisas da natureza imitam outras. Em seguida, é necessário saber que a arte não imita simplesmente isto que se vê, mas ela se eleva aos princípios racionais [toûs lógous] dos quais a natureza deriva. Além disto, elas ainda produzem muitas realidades por si próprias, já que elas complementam quando quer que algo falte: porque elas possuem beleza. Pois quando Fídias produziu [poiésas] o seu Zeus, não se voltou para nada que fosse sensível [aisthetòn], mas apreendeu o modo como seria se Zeus quisesse aparecer para nossos olhos.

Vê-se claramente a superação da crítica platônica: a arte agora ocupa a mesma posição que a psyché, identificada como phýsis, pois copia o mundo inteligível. A arte se eleva até os princípios racionais, lógoi, a partir dos quais também o kósmos, com sua bela ordem, é derivado. A arte se torna, como a phýsis, projeto de mímesis do noûs no mundo sensível, e assim trilha a jornada de Ulisses rumo à pátria. A criação de objetos artísticos, em certo sentido, tem a mesma função da criação do próprio universo: completar, na medida do possível, a realidade imperfeita para que ela possa ser a melhor cópia do perfeito. E a imagem do hieróglifo aí se encaixa de modo magnífico: trata-se da melhor linguagem para expressar o concentrado noético das belezas inteligíveis. Assim, a arte é linguagem-ascese, pois é imagem que apresenta o caminho rumo ao belo, é proposta de prática-estética. Vejamos como Plotino nos fala:

Parece-me que os sábios egípcios, compreendendo - ou através de uma ciência exata ou através de um conhecimento inato - aquelas coisas que gostariam de apresentar com sabedoria, não usavam os caracteres dos alfabetos que seguem os discursos ou as proposições que copiam sons e os proferimentos dos axiomas. Mas eles gravam imagens [ágalma], uma única para cada realidade, entalhando-as nos templos, apresentando o caráter não discursivo do Inteligível [ekeinoû], pois cada uma das imagens é uma ciência, uma sabedoria, que é um substrato agregado, não um pensamento desenvolvido nem uma deliberação. ${ }^{37}$

As imagens [ágalma, que também significa estátuta] são cópias sensíveis da unidade simpática das idéias. Cada uma delas é uma apresentação sintética [athróon] agregada daquilo que é unificado no mundo inteligível. As imagens egípcias, provavelmente os hieróglifos ${ }^{38}$, servem como exemplo do poder reunificador das imagens artísticas, pois são um caminho rumo ao mundo inteligível.

A definição explícita de beleza no tratado I, 6 [1], que já apresentamos neste texto, nos remete ao deleite que se sente ao contemplar a forma presente na matéria ${ }^{39}$ :

Mas como, então, são belas as coisas de lá e estas daqui? Afirmamos que estas são belas por participação nas Idéias, já que todo amorfo, que é capaz por natureza de receber forma e Idéia, é feio e excluído da divina razão formativa ${ }^{40}$ na medida em que está alijado da Idéia e da razão formativa: o feio absoluto é assim. ${ }^{41}$ 
Tal deleite que percebemos na forma é também um processo de anaminése, pois reconhecemos a semelhança entre a nossa natureza e aquela da forma. A busca pela construção de objetos artísticos se torna, assim, a busca daquilo que é do nosso mesmo génos, o syngénes, pois em verdade estamos na busca por nós mesmos. Forjar o belo na matéria é buscar encontrar aquilo que amamos, que é o mais próprio de nossa natureza, o inteligível. Assim, toda a escada própria da erótica dialética ascendente configura a compreensão sublime da arte em Plotino: a beleza percebida no mundo sensível é o primeiro passo do lembrar-se de si mesmo, o qual deve ser superado na descoberta amorosa das realidades psíquicas. Uma arte-anaminese. Forjando o belo no sensível, o artista se apresenta como um apaixonado pelas realidades mais intensamente belas do psíquico, e, num próximo momento, também a psyché se apaixona pelo inteligível, e mais belas ainda serão suas produções. Vale lembrar que na própria subida erótica de Diotima, o aprendiz do Belo vai produzindo discursos cada vez mais belos em cada etapa da descoberta de um novo horizonte de beleza. A nostalgia do além nos lança a criar belezas ao longo de nossa subida.

Assim, o próprio movimento de conquista de uma vida virtuosa se confunde com a produção de objetos artísticos, pois também a virtude é uma mímesis do inteligível, como o magnífico Zeus de Fídias. Não cessar de esculpir a própria estátua é buscar perceber o resplendor ofuscante da sophrosyne assentada sobre o trono divino do inteligível, qual o deus, pai dos deuses e dos homens.

Percorremos, de modo geral, as características básicas da estética em Plotino, procurando esclarecer as imbricações necessárias entre estética e a proposta ética de conversão rumo ao inteligível. A arte se mostra como um processo de descoberta daquilo que é mais propriamente nosso, de nosso nível mais verdadeiro, o noûs. $\mathrm{Na}$ autodescoberta apaixonada do noûs, o aprendiz do Belo se torna sua maior obra de arte, a escultura de si mesmo, que faz brilhar em sua própria vida o resplendor da virtude, mimese do inteligível. Também o artista, na nossa acepção do termo, ao criar sua obra exterior, faz brilhar sensivelmente os seus amores inteligíveis, unificando-se progressivamente com as esferas superiores. Suas obras são frutos do processo de conversão ao mundo das verdadeiras belezas, o noûs. Tais obras, cópias diretas do mundo inteligível (e não cópias de cópias), são vestígios Daquele Belo, indicações que nos apontam para a transcendência, são obras-anaminese, que nos fazem escalar o caminho da ascese: arte-ética, a vida como um ato de artista.

\footnotetext{
* Marcus Reis Pinheiro é doutor em filosofia pela PUC/RJ.

* O autor agradece à FAPERJ pelo apoio financeiro na realização de sua pesquisa de pósdoutorado sobre Plotino.

${ }^{1}$ Plotino nasce em Licopolis, no Egito, em 203 d.c. e morre em 270 d.c. Sobre sua vida, ver Vita Plotini, texto de seu aluno Porfírio que, na maioria das edições, é publicado junto com as Enéadas.
} 
${ }^{2}$ Por exemplo: V, 8 [31], 7, 10-12. Trata-se do oitavo tratado, da quinta enéada, que é o trigésimo primeiro que Plotino escreveu. Mas a citação também indica que se trata das linhas 10 até 12 do sétimo capítulo.

${ }^{3}$ A palavra hipóstase em português (que em seu sentido filósofico é sinônimo de 'substância', mas que quer também dizer 'sedimento'), é diretamente derivada de hypóstasis do grego, que significa algo que existe por si mesmo, algo realmente existente e unicamente dependente de si mesmo. Etimologicamente, a palavra é composta pelo prefixo hypo, que quer dizer 'por baixo' e stasis, 'posição'. Assim, ela é também etimologicamente um sinônimo para substância (sub- = em baixo, stancia $=$ estar $)$.

${ }^{4} \mathrm{~V}, \mathrm{I}[10], 1$

${ }^{5}$ GATTI, M. L. "Plotinus: the platonic tradition and the foundation of Neoplatonism" In: GERSON, L. P. (org.) The Cambridge Companion to Plotinus. Cambridge: Cambridge University Press, 1996, p. 31.

${ }^{6}$ É sempre importante lembrar que a diferença entre tempo lógico e tempo cronológico, já presente no Timeu de Platão, é usada por Plotino ao descrever o processo de geração das hipóstases. Apenas em um sentido figurado é que podemos dizer que uma hipóstase vem temporalmente 'depois' da outra. O depois deve ser entendido apenas logicamente e não cronologicamente. Ver Timeu, 34a-c.

${ }^{7} \mathrm{O}$ termo conversão é usado para designar o ato das hipóstases inferiores frente às superiores.

${ }^{8}$ REALE, G. História da Filosofia Antiga. São Paulo: Loyola, 1993, p. 459.

9 Tal termo teria sua origem na interpretação de Plotino do diálogo Parmênides 144e. Ver o apêndice de Luc Brisson em Parménide. Paris: Flammarion, 1999.

${ }^{10}$ No entanto, a multiplicidade do Intelecto não é tão simples assim, como mostra Reale, op. cit., p. 465: "Enquanto incorpóreos, o Ser e o Intelecto não podem ser entendidos como muitos, como se fossem divididos nas várias Idéias, ou como se fossem fracionados em partes fisicamente separadas umas das outras [...]". Há uma alteridade inteligível, da qual já falou Platão no Sofista, que configura a multiplicidade do Intelecto.

11 O pré-socrático Parmênides é uma fonte muito importante para nosso filósofo. V, 6 [24] 6 "Portanto, se é Ser também é Intelecto, e se é Intelecto também é Ser, e o pensar vai juntamente com o ser". Ver também V, 1 [10], 8; III, 8 [30], 8; VI, 7 [38], 41; I, 4 [46], 10.

${ }^{12} \mathrm{~V}, 1[10] 3$.

${ }^{13} \mathrm{~V}, 1[10] 6$.

${ }^{14}$ Há diversas passagens em Plotino sobre a matéria, algumas delas são as seguintes: II, 4 [12], 16 Matéria como não ser. I, 8 [51], 14, Matéria não faz unidade com a Forma. III, 6 [26], 13, Espelho sem forma que reflete o noûs, etc.

15 Toda esta descrição que acabamos de fazer pode parece dogmática e sem fundamentos razoáveis. No entanto, devemos situar a metafísica de Plotino dentro da tradição platônica que, com o chamado Médio-Platonismo, já pensa a realidade em uma estrutura triádica. Ver DILLON, J. The Middle Platonists. Ithaca: Cornell University Press, 1977.

${ }^{16}$ Que se encontra inserido no discurso de Sócrates, 201d - 212c.

$17244 a-257 b$

18 A importância deste termo, askesis, utilizado filosoficamente primeiro pelos cínicos, é fundamental em Plotino.

19 248d: "[...] mas a alma que viu maior quantidade de (formas) entrará no nascimento de um homem filósofo ou de um amante do belo [philokalou] ou de um músico [mousikou] ou de um amante [erotikou]. 
${ }^{20}$ I, 4 [20], 1 Sobre a dialética.

${ }^{21}$ Vale salientar que a natureza de um músico é aquela vinculada a todas as ditas belas artes, os amantes das musas.

${ }^{22}$ Metochêi eídous phamèn taûta. 1,6 [1], 2, 13-14.

${ }^{23} 210 a-212 b$

${ }^{24}$ Vale uma ressalva interessante: tanto Platão quanto Plotino não negam absolutamente a beleza do mundo corpóreo, mas defendem que tal Beleza provém de uma esfera superior que contém mais radicalmente aquilo que se deseja.

${ }^{25}$ tò polù pélagos toû kaloû Banquete, 210d4. Plotino interpreta a passagem da ascese erótica de Diotima, em que o aprendiz de belo se volta para as belezas da ciência, como o processo de se alcançar o nível noético.

${ }^{26}$ Há certa recorrência desta expressão em Plotino: ver II, 1 [40], 7, 47-48; IV, 5 [29]; II, 9 [33], 17, 4.

${ }^{27}$ Termo provavelmente cunhado pelo próprio Plotino. Ver V, 8 [31], 8 e 13; V, 5 [32], 12; VI, 7 [38], 3229 e 33, 20. Esta idéia já aparece na República, na famosa imagem do sol como sumo transcendente, 509a7.

${ }^{28} \mathrm{VI}, 7$ [38], 32, 25 e 33, 14.

${ }^{29} \mathrm{VI}, 7$ [38] 35, 21-27.

${ }^{30}$ I, 6 [1], 4, 1

${ }^{31}$ I, 6 [1], 7.

${ }^{32}$ Aqui estou pensando especialmente no tratado 1, que é estilisticamente uma diatribe: forma dialógica que interpreta um texto clássico (no caso, o Banquete e o Fédon), desenvolvido por perguntas e respostas, como em uma aula. Tal estilo teve seu início nas aulas cínicas, e Teles, o cínico, teria sido o primeiro a compor tratados em diatribe. Ver a respeito a introdução da tradução de Brehier das Enéadas, pela Belles Lettres, pp. XXXIff.

${ }^{33}$ Seria interessante fazer referência à "metafísica do artista" de O nascimento da tragédia de Nietzsche.

${ }^{34} \mathrm{VI}, 8,[39] 15$

${ }^{35}$ Ver LACROSSE, J. L'amour chez Plotin. Ousia: Bruxelles, 1995.

${ }^{36}$ Em português temos a tradução detalhadamente comentada de SOARES, "Plotino, Acerca da Beleza Inteligível". In: Kritérion, 107, Jan-Jun 2003, UFMG.

${ }^{37} \mathrm{~V}, 7$ [31],6. Tradução baseada na de SOARES, já citada, com modificações.

${ }^{38}$ Os comentadores são unânimes em afirmar que Plotino desconhecia que os hieróglifos, possível objeto a que se refere neste texto, têm também uma estrutura alfabética em sua linguagem.

${ }^{39}$ É claro que a simetria estóica nunca poderá dar conta da profundidade divino do esplendor da beleza das realidades não sensíveis. Que tipo de simetria haveria no ato justo?

${ }^{40}$ Razão Formativa traduz a refinada concepção dada, em alguns usos, ao termo lógos em Plotino.

${ }^{41}$ I, 6 [1], 2 (Tradução minha). 